

\section{NOTICE}

The submitted manuscript has been offered by an employee of the Alliance for Sustainable Energy, LLC, (ASE) a contractor of the US Government under Contract No. DE-AC36-08GO28308. Accordingly, the US Government and ASE retain a nonexclusive royalty-free license to publish or reproduce the published form of this contribution, or allow others to do so, for US Government purposes.

This report was prepared as an account of work sponsored by an agency of the United States government. Neither the United States government nor any agency thereof, nor any of their employees, makes any warranty, express or implied, or assumes any legal liability or responsibility for the accuracy, completeness, or usefulness of any information, apparatus, product, or process disclosed, or represents that its use would not infringe privately owned rights. Reference herein to any specific commercial product, process, or service by trade name, trademark, manufacturer, or otherwise does not necessarily constitute or imply its endorsement, recommendation, or favoring by the United States government or any agency thereof. The views and opinions of authors expressed herein do not necessarily state or reflect those of the United States government or any agency thereof.

Available electronically at http://www.osti.gov/bridge

Available for a processing fee to U.S. Department of Energy and its contractors, in paper, from:

U.S. Department of Energy

Office of Scientific and Technical Information

P.O. Box 62

Oak Ridge, TN 37831-0062

phone: 865.576 .8401

fax: 865.576 .5728

email: mailto:reports@adonis.osti.gov

Available for sale to the public, in paper, from:

U.S. Department of Commerce

National Technical Information Service

5285 Port Royal Road

Springfield, VA 22161

phone: 800.553 .6847

fax: 703.605.6900

email: orders@ntis.fedworld.gov

online ordering: http://www.ntis.gov/ordering.htm 


\title{
Accelerated Stress Testing and Diagnostic Analysis of Degradation in CdTe Solar Cells
}

\author{
David S. Albin \\ National Renewable Energy Laboratory, 1617 Cole Blvd., Denver, CO, USA 80401
}

\begin{abstract}
Solar cell module reliability is inextricably linked to cell-level reliability. This is particularly so with thin-film technologies. In $\mathrm{CdTe}$, reliability issues historically associate with back contact stability and the use of $\mathrm{Cu}$ as an extrinsic dopant. Using a simple approach by which identical cells are heated under open-circuit bias and 1-sun illumination, degradation activation energies of 0.63 and $2.94 \mathrm{eV}$ in laboratory-scale CdS/CdTe devices were identified in the accelerated stress temperature range of 60 to $120^{\circ} \mathrm{C}$. At lower stress temperatures, cell performance changes were linearly correlated with changes in both fill factor $(\mathrm{FF})$ and short-circuit current $\left(\mathrm{J}_{\mathrm{sc}}\right)$. At higher stress temperatures, changes in efficiency were correlated with changes in $\mathrm{FF}$ and open-circuit voltage $\left(\mathrm{V}_{\mathrm{oc}}\right)$. The measured activation energy of 0.63 is associated with $\mathrm{Cu}$-diffusion. During the early stage of stress testing, which may provide additional back contact annealing, improvements in FF were due to Cu-diffusion. Decreased performance observed at longer stress times (decreased $\mathrm{FF}$ and $\mathrm{V}_{\mathrm{oc}}$ ), according to a two-diode Pspice model, were due to both increased space-charge recombination (near the junction) and decreased recombination in the bulk. Kirkendall void formation (S-outdiffusion) at the $\mathrm{CdS} / \mathrm{CdTe}$ interface is given as responsible for the $2.9 \mathrm{eV}$ degradation mechanism.
\end{abstract}

Keywords: CdTe solar cell, degradation mechanism, recombination, activation energy, Kirkendall effect

\section{INTRODUCTION}

Polycrystalline CdS/CdTe devices show good solar cell potential with laboratory efficiencies of $16.5 \%$ having been demonstrated [1]. In addition to considerable research in maximizing performance, recent work has also focused on cell stability due to concerns surrounding the use of $\mathrm{Cu}$ as a dopant in these structures $[2,3,4]$. Stress testing typically involves elevated temperature as a means to accelerate degradation [5]. To date, temperatures ranging from 65 to $200{ }^{\circ} \mathrm{C}$ have been used in similar CdTe stability studies. Though most use fixed stress temperatures, others have considered temperature itself as a variable [6,7]. Recently, it has been reported that processing can impart strong differences in stability, and thus potentially different degradation mechanisms [8,9]. Viable stress protocols require acceleration temperatures that only invoke mechanisms expected under actual use conditions. The primary goal of this study was to ascertain the presence and types of mechanisms affecting $\mathrm{CdS} / \mathrm{CdTe}$ device stability in the temperature range of 60 to $120^{\circ} \mathrm{C}$. It should be noted that the results presented here are specific to cells made using the specific growth conditions described here.

\section{EXPERIMENTAL PROCEDURE}

Polycrystalline CdS and CdTe films were deposited by chemical bath deposition (CBD) and close-spaced sublimation (CSS) respectively. These layers were deposited on 1.5" x 1.5" tin-oxide coated Corning 7059 glass superstrates. The CBD solution consisted of $550 \mathrm{ml}$ DI water, $8 \mathrm{ml}$ of $0.033 \mathrm{M}$ cadmium acetate, $15 \mathrm{ml}$ of reagent-grade ammonium hydroxide (28-30\%), and $4.7 \mathrm{ml}$ of $1.0 \mathrm{M}$ ammonium acetate heated to $92{ }^{\circ} \mathrm{C}$ where it was then titrated $(2 \mathrm{ml}$ at $10 \mathrm{~m}$ intervals) with $8 \mathrm{ml}$ of $0.067 \mathrm{M}$ thiourea solution for $37 \mathrm{~m}$. The CSS process was subsequently performed at a substrate growth temperature of $620^{\circ} \mathrm{C}$ and CdTe source temperature of $660{ }^{\circ} \mathrm{C}$ in an ambient of 1 torr $\mathrm{O}_{2}$ and 15 torr $\mathrm{He}$ for $5 \mathrm{~m}$. This processing resulted in CdS and CdTe layers of approximately $80 \mathrm{~nm}$ and 9-10 microns respectively. Resulting glass $/ \mathrm{SnO}_{2} / \mathrm{CdS} / \mathrm{CdTe}$ layers were then annealed at $400{ }^{\circ} \mathrm{C}$ suspended in a CSS configuration over a pelletized, anhydrous $\mathrm{CdCl}_{2}$ source in an ambient of 100 torr $\mathrm{O}_{2}$ and 400 torr helium for $8 \mathrm{~m}$. Prior to contact application, a 1:88:35 volume mixture of $\mathrm{HNO}_{3}: \mathrm{H}_{2} \mathrm{PO}_{4}: \mathrm{H}_{2} \mathrm{O}$ acid etch was used to remove surface oxides and produce a Te-rich layer to 
improve initial performance [10] and stability [9]. Contacts consisted of a Cu-doped, graphite paste mixture brushed onto the etched CdTe surface and subsequently annealed in $\mathrm{He}$ at $280^{\circ} \mathrm{C}$ for $25 \mathrm{~m}$ followed by the final application of a Ag-paste (Acheson) conductor. The average efficiency of 24 similarly made superstrate CdTe solar cells was measured using a calibrated, xenon-arc, Oriel solar simulator to be 12.6\%. A total of 6 individual cells were tested at each of 4 different stress temperatures for times exceeding 2000 hours.

The stress station consisted of two parts: an illumination source supported over individually heated sample holders. Illumination was supplied using a xenon-arc, Atlas CPS + Suntest station calibrated to deliver 1-sun at the sample test plane over extended periods of time. A borosilicate filter was used to eliminate UV radiation below $\sim 300$ $\mathrm{nm}$. Approximately $0.75 \mathrm{~cm}^{2}$ cell samples were placed in aluminum fixtures designed to hold the cells facing this illumination (glass-side up) in an open-circuit configuration (no backcontact-to-tin oxide shorting). These fixtures were attached to aluminum blocks independently heated by $300 \mathrm{~W}$ cartridge heaters. Thermocouples were inserted into these blocks to provide feedback for individual RKC-CB100 temperature-controllers. Calibration curves correlating aluminum block temperature with true junction temperatures (using thermocouples mounted to dummy cell back contacts) were performed prior to stress testing. Cell stress temperature was monitored continuously during tests and was fixed constant at $60,80,100$, and $120^{\circ} \mathrm{C}$ during the test duration within $\pm 1{ }^{\circ} \mathrm{C}$. Stress testing was performed in a laboratory environment where relative humidity (RH) was controlled at $\sim 30 \%$ at $25{ }^{\circ} \mathrm{C}$. At stress temperatures of 120 to $60{ }^{\circ} \mathrm{C}$, this corresponds to $\sim 0.5$ to $4.8 \% \mathrm{RH}$ respectively.

Cell current and voltage $(\mathrm{JV})$ measurements were performed on all cells initially $(\mathrm{t}=0)$ and after stress $(\mathrm{t}>0)$. A previous [7] study of cell performance as a function of stress temperature reported an activated degradation energy of $\sim 1 \mathrm{eV}$. Using this value, stress measurement times were targeted in order to best compare device performance stressed at different temperatures. At these pre-determined times, devices were removed as a group, stored in the dark at $25{ }^{\circ} \mathrm{C}$ for 12-24 hrs, and then had their dark and light JV characteristics measured. These measurements were used to determine $\mathrm{V}_{\mathrm{oc}}, \mathrm{FF}, \mathrm{J}_{\mathrm{sc}}$, and efficiency $(\eta \%)$. In order to extract information regarding recombination, series and shunt resistance, as well as back contact related parameters, measured JV curves were fit to a discrete element circuit model shown in Figure 1 using a freeware version of PSpice (Orcad PSpice Student Ver. 9.1).

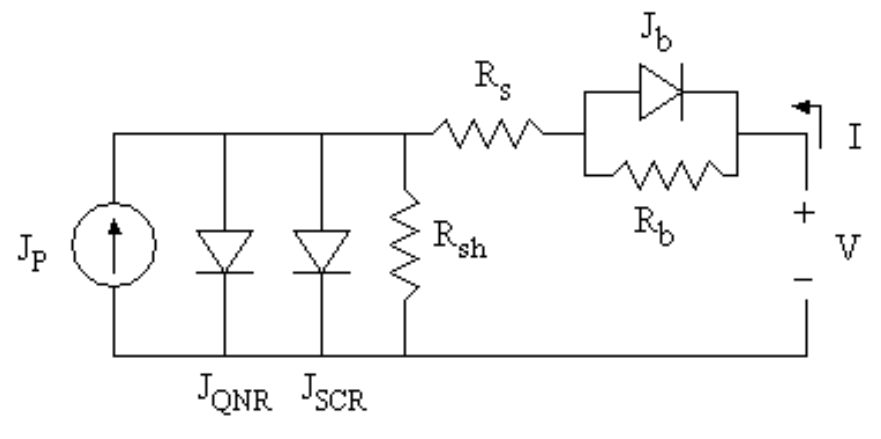

Figure 1. Circuit model used to extract device parameters.

By default, PSpice uses Si diodes where forward current equals the sum of the normal and recombination currents and the diode quality factor, N, varies between 1 and 2 depending upon the particular default Si diode used. In this model, a parallel combination of forward-biased diodes was used to independently simulate recombination currents in the quasi-neutral $\left(\mathrm{J}_{\mathrm{QNR}}\right)$ and space-charge $\left(\mathrm{J}_{\mathrm{SCR}}\right)$, i.e., depletion regions by effectively setting the recombination term in the default diode template to zero (e.g., $\mathrm{I}_{\text {rec }}=$ recombination current $=0$ ), and $\mathrm{N}$ to either $1(\mathrm{QNR})$ or $2(\mathrm{SCR})$. The theoretical basis for this two-diode model as a general expression for the current produced in a solar cell can be found in ref.[11]. Though useful for deconvoluting individual forward-current terms, this model assumes Shockley-Read-Hall recombination via a single, mid-gap trap. Such ideal conditions are not expected. The presence of impurities and structural defects (e.g., grain boundaries, and interface states introduced by the relatively large lattice-mismatch $(\sim 11.7 \%)$ between $\mathrm{CdS} / \mathrm{CdTe})$ complicate recombination beyond this single-level approximation. Unfortunately, more sophisticated models (e.g., the use of AMPS-1D [12]) in which recombination can be more accurately studied were deemed as having too many "curve-fitting parameters" for this study. The back contact behavior was modeled using a combination reverse-biased diode $\left(\mathrm{J}_{\mathrm{b}}\right)$ and shunt conductance $\left(1 / \mathrm{R}_{\mathrm{b}}\right)$ that was previously shown capable of fitting JV characteristics in the first quadrant [13]. 


\section{RESULTS AND DISCUSSION}

$\mathrm{JV}$ data for two representative devices tested at 60 and $120^{\circ} \mathrm{C}$ immediately after fabrication $(\mathrm{t}=0)$, and after 1 and $723 \mathrm{hrs}$ of stress are shown in Figure 2. Initially, most devices showed cross-over of the dark and light curves which was removed after the first hour of light soak. Cross-over is attributed to photoconductivity introduced by $\mathrm{Cu}$ diffusion resulting from the final $280{ }^{\circ} \mathrm{C}$ back contact anneal [14]. Since cross-over is metastable, affects performance primarily in the first quadrant, and is effectively removed by an initial light soak, following discussions regarding changes in device performance sometimes use $\mathrm{t}=1 \mathrm{hr}$ measurements as approximating the initial performance.
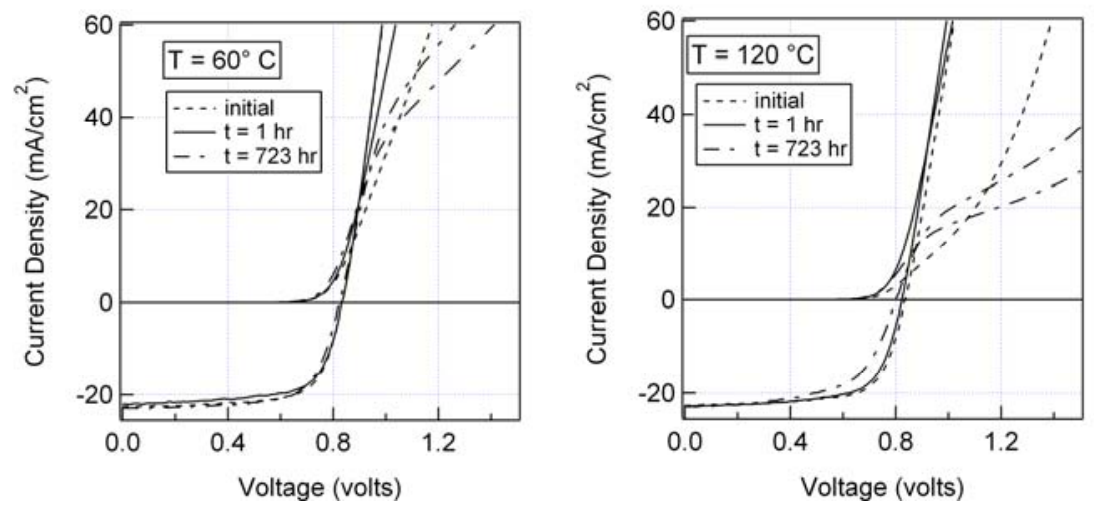

Figure 2. JV data for representative cells stressed at extreme values of time and temperature.

As shown in Figure 2, devices stressed at 60 and $120{ }^{\circ} \mathrm{C}$ show roll-over in the first quadrant due to increasing back contact barrier height. The latter was observed to increase with temperature and time indicating a gradual degradation of the back contact during stress. Figure 3 plots the average values of $\mathrm{V}_{\mathrm{oc}}, \mathrm{J}_{\mathrm{sc}}, \mathrm{FF}$, and $\eta \%$ for the 6 devices tested at each stress temperature as a function of stress time out to $723 \mathrm{hrs}$.
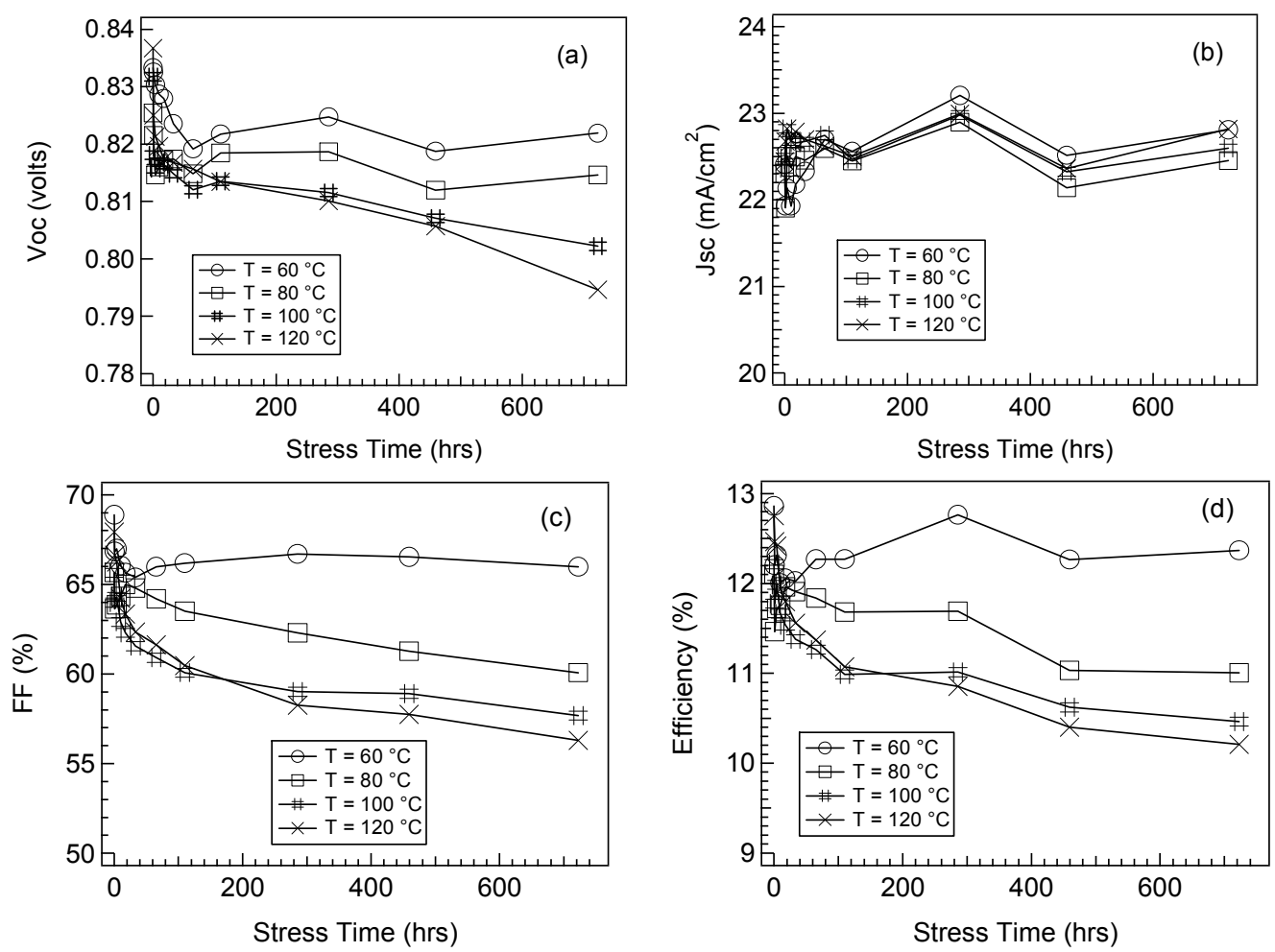

Figure 3. Changes in $V_{o c}(a), J_{s c}(b), F F(c)$, and $\eta \%$ (d) as a function of time and stress temperature 
By visual observation, it appears that changes in cell performance $(\eta \%)$ mimic similar changes in both $V_{\text {oc }}$ and FF. These modal observations, i.e., how degradation manifests itself, provide insight regarding cell degradation mechanisms. To better quantify this effect, linear regression fits of the \%change $(t>0)$ relative to the initial measurement $(\mathrm{t}=0)$ of $\eta \%$ (deltaEff) vs. \%changes in $\mathrm{V}_{\mathrm{oc}}\left(\mathrm{delta}_{\mathrm{oc}}\right), \mathrm{J}_{\mathrm{sc}}\left(\right.$ deltaJ $\left._{\mathrm{sc}}\right)$, and $\mathrm{FF}$ (deltaFF) were made from each combination of $\eta \%, V_{\mathrm{oc}}, \mathrm{J}_{\mathrm{sc}}$, and FF measured during stress testing. (Note that these are not true differentials and thus, not derivable in a purely analytical fashion.) These plots for measurements performed at $\mathrm{T}=60^{\circ} \mathrm{C}$ and $120^{\circ} \mathrm{C}$ are shown in Figure 4. The horizontal line indicates the overall response mean for each parameter, while the off-horizontal lines indicate the regression (solid-line) bracketed by the $95 \%$ confidence intervals (dashed-lines) for the fit. Also shown in this figure are values of $\mathrm{R}^{2}$ which equals the ratio of the linear model sum of squares to the total sum of squares. In other words, $\mathrm{R}^{2}$ measures the proportion of the total data variance around the mean explained by the linear fit. $A R^{2}=1.0$ indicates that all data variation can be explained by the fit, while $\mathrm{R}^{2}=0$ indicates that the model serves no better predictor than the overall response (horizontal line) mean.
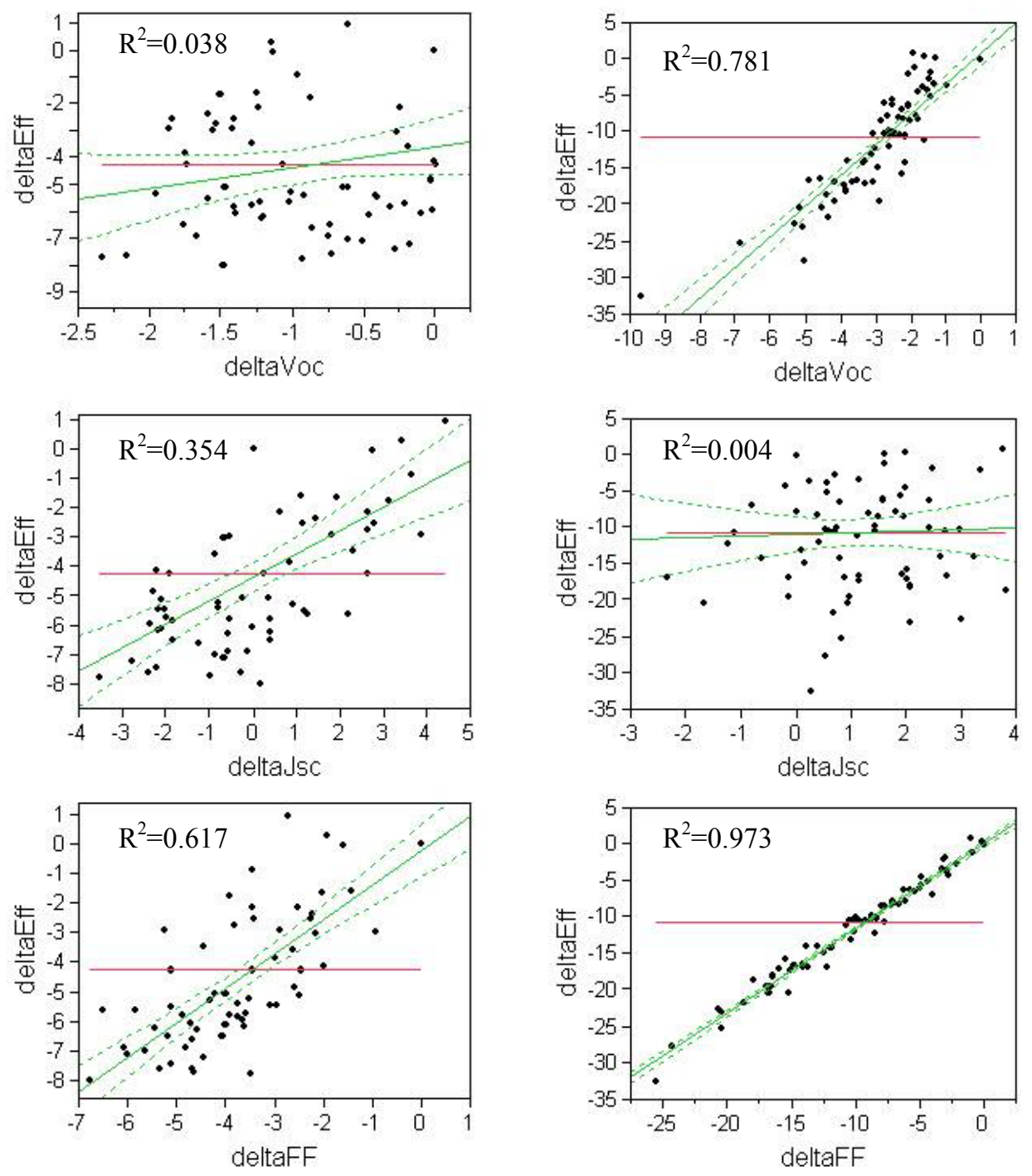

Figure 4. Cell Performance correlations of Performance change with changes in $\mathrm{V}_{\mathrm{oc}}$ (top row), $\mathrm{J}_{\mathrm{sc}}$ (middle row), and FF (bottom row) measured during stress testing at $\mathrm{T}=60^{\circ} \mathrm{C}$ (left column) and $120^{\circ} \mathrm{C}$ (right column). 
It is quite obvious that changes in cell performance, deltaEff, can largely be attributed to changes in FF at both $\mathrm{T}=60$ and $120{ }^{\circ} \mathrm{C}$. What is not obvious from a casual observation of Figure 3 however, is the correlation between deltaEff and deltaJ $\mathrm{s}_{\mathrm{sc}}$ observed at $\mathrm{T}=60{ }^{\circ} \mathrm{C}$. This latter mode appears to be temperature dependent, and is no longer statistically significant at $\mathrm{T}=120{ }^{\circ} \mathrm{C}$. This same temperature dependence is also observed for $\mathrm{V}_{\text {oc }}$. Repeating this procedure at all stress temperatures, values of $\mathrm{R}^{2}$ for deltaEff vs. deltaV $\mathrm{V}_{\mathrm{oc}}$, deltaJ $\mathrm{sc}_{\mathrm{sc}}$, and deltaFF were calculated and plotted as a function of temperature in Figure 5.

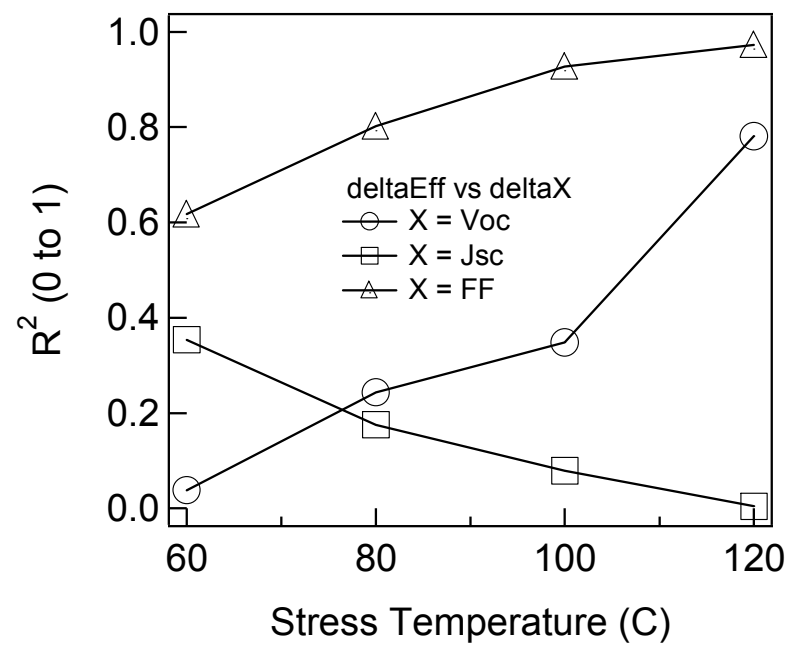

Figure 5. Correlation of cell performance changes with changes in $V_{o c}, J_{s c}$, and FF.

As seen in Figure 5, there are systematic variations in how well changes in cell performance (deltaEff) correlate with changes in $\mathrm{V}_{\mathrm{oc}}, \mathrm{J}_{\mathrm{sc}}$, and $\mathrm{FF}$. At the lowest temperature of stress, $60{ }^{\circ} \mathrm{C}$, changes in $\eta \%$ can be associated with changes in both $\mathrm{FF}$, and $\mathrm{J}_{\mathrm{sc}}$. As temperature increases, the correlation of deltaEff with deltaFF increases to almost a perfect correlation of 1.0. At the same time, the correlation of deltaEff with deltaJ $\mathrm{J}_{\mathrm{sc}}$ gradually decreases and is replaced by a very strong correlation with delta $\mathrm{V}_{\mathrm{oc}}$. It must be noted however, that at all temperatures, changes in FF remain the most dominant predictor of overall cell efficiency during stress, and thus, is an important parameter to monitor.

During early times of stress, some interesting, non-monotonic changes in cell parameters were observed. A magnified view of FF as a function of temperature and time shows this in Figure 6 . The time axis has been adjusted to emphasize these subtle changes.

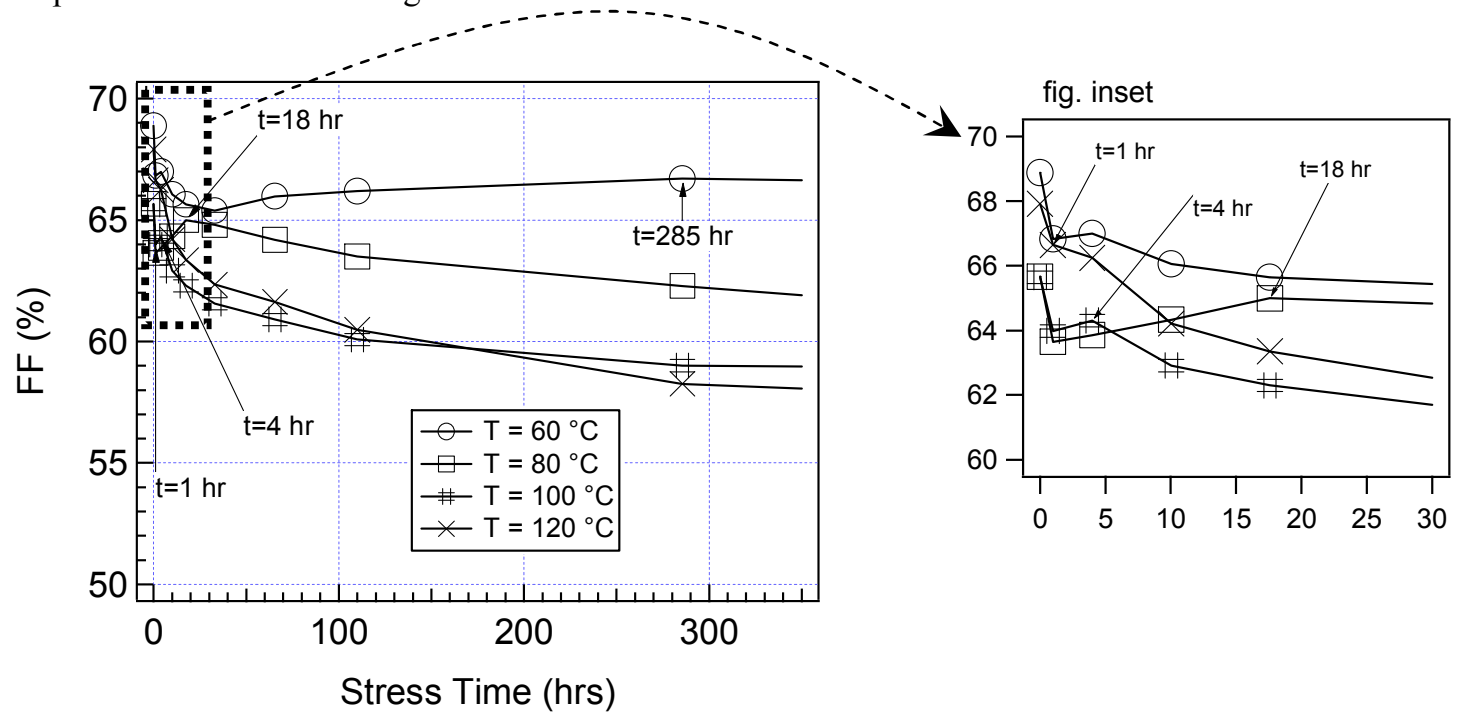

Figure 6. Non-monotonic changes in cell FF observed during initial stress. 
As seen in Figure 6, FF was observed to undergo a slight improvement in value (after an initial decrease) at different times dispersed by what appears to be temperature. The maximum value in FF occur at $\mathrm{t}=285$, 18, 4 , and $1 \mathrm{hrs}$ for cells stressed at $60,80,100$, and $120^{\circ} \mathrm{C}$, respectively. These short term improvements represent possible benefits of continued annealing of the cells immediately after fabrication. It is unclear whether these benefits are due to thermal effects alone, or a combination of light and heat. With longer periods of stress, as seen in Figure 3, FF once again begins to decrease monotonically. In order to gain some insight into why FF decreased at longer stress times, JV curves were reproduced using Pspice and the discrete circuit model shown in Figure 1. A compilation of model parameters extracted for devices stressed at 60 and $120^{\circ} \mathrm{C}$ after 1 and $723 \mathrm{hrs}$ of stress is given in Table 1.

\begin{tabular}{|c|c|c|c|c|c|}
\cline { 3 - 6 } \multicolumn{2}{c|}{} & unstressed (t=1 hr) & \multicolumn{2}{c|}{ stressed (t=723 hr) } \\
\hline Parameter & T (C) & Dark & Light & Dark & Light \\
\hline JQNR & 60 & $1.5 \mathrm{E}-16$ & $4.0 \mathrm{E}-17$ & $2.7 \mathrm{E}-16$ & $3.0 \mathrm{E}-18$ \\
\hline $\mathrm{JSCR}$ & 60 & $7.0 \mathrm{E}-10$ & $2.0 \mathrm{E}-09$ & $6.0 \mathrm{E}-10$ & $2.3 \mathrm{E}-09$ \\
\hline $\mathrm{Rs}$ & 60 & 3.0 & 1.6 & 0.8 & 0.5 \\
\hline $\mathrm{Rsh}$ & 60 & $1.0 \mathrm{E}+05$ & 400 & $1.0 \mathrm{E}+08$ & 600 \\
\hline $\mathrm{Jb}$ & 60 & none & none & 0.027 & 0.038 \\
\hline $\mathrm{Rb}$ & 60 & none & none & 15.0 & 14.7 \\
\hline $\mathrm{JQNR}$ & 120 & $5.0 \mathrm{E}-16$ & $1.0 \mathrm{E}-16$ & $8.2 \mathrm{E}-16$ & $1.0 \mathrm{E}-17$ \\
\hline $\mathrm{JSCR}$ & 120 & $4.4 \mathrm{E}-10$ & $2.0 \mathrm{E}-09$ & $5.8 \mathrm{E}-10$ & $4.0 \mathrm{E}-09$ \\
\hline $\mathrm{Rs}$ & 120 & 2.2 & 1.4 & 3.0 & 1.0 \\
\hline $\mathrm{Rsh}$ & 120 & $1.0 \mathrm{E}+08$ & 500 & $1.0 \mathrm{E}+08$ & 325 \\
\hline $\mathrm{Jb}$ & 120 & 0.900 & 0.990 & 0.013 & 0.015 \\
\hline $\mathrm{Rb}$ & 120 & 9.0 & 9.0 & 45.0 & 29.0 \\
\hline
\end{tabular}

Table 1. Two-diode fit parameters for unstressed $(\mathrm{t}=1 \mathrm{hr})$ and stressed $(\mathrm{t}=723 \mathrm{hrs})$ cells $(\mathrm{J}$ and $\mathrm{R}$ terms shown in units of $\mathrm{A} / \mathrm{cm}^{2}$ and ohms $\cdot \mathrm{cm}^{2}$ respectively)

Back contact behavior is modeled in Pspice using a diode leakage current term $\mathrm{J}_{\mathrm{b}}$ that is inversely proportional to barrier height at the CdTe/backcontact interface. The values $\mathrm{J}_{\mathrm{QNR}}$ and $\mathrm{J}_{\mathrm{SCR}}$ represent the forward leakage currents associated with recombination in the quasi-neutral and space-charge (depletion) regions respectively. Though $\mathrm{J}_{\mathrm{SCR}}$ has an $\exp (\mathrm{qV} / 2 \mathrm{kT})$ voltage dependence, the large magnitude of this forward current dominates recombination, and thus FF, in the cell power quadrant. It is only at voltages near and above $\mathrm{V}_{\mathrm{oc}}$ that $\mathrm{J}_{\mathrm{QNR}}$ makes a contribution to forward current. As seen in Table 1, space-charge recombination $\left(\mathrm{J}_{\mathrm{SCR}}\right)$ measured for the cells under illumination increased slightly with increasing stress temperature $\left(2.0 \cdot 10^{-09}\right.$ increased slightly to $2.3 \cdot 10^{-09} \mathrm{~A} / \mathrm{cm}^{2}$ at $\mathrm{T}=60{ }^{\circ} \mathrm{C}$ and $2.0 \cdot 10^{-09}$ increased to $4.0 \cdot 10^{-09} \mathrm{~A} / \mathrm{cm}^{2}$ at $\left.\mathrm{T}=120^{\circ} \mathrm{C}\right)$. At the same time, quasi-neutral region recombination $\left(\mathrm{J}_{\mathrm{QNR}}\right)$ for the same cells actually decreased with increasing stress temperature $\left(4.0 \cdot 10^{-17}\right.$ down to $3.0 \cdot 10^{-18} \mathrm{~A} / \mathrm{cm}^{2}$ at $\mathrm{T}=60{ }^{\circ} \mathrm{C}$ and $1.0 \cdot 10-{ }^{16}$ down to $1.0 \cdot 10^{-17} \mathrm{~A} / \mathrm{cm}^{2}$ at $\mathrm{T}=120{ }^{\circ} \mathrm{C}$ ). The improvement in $\mathrm{J}_{\mathrm{QNR}}$, and smaller increase in $\mathrm{J}_{\mathrm{SCR}}$ helps to explain why $\mathrm{V}_{\mathrm{oc}}$ degradation stabilizes at stress temperatures of 60 to $80^{\circ} \mathrm{C}$ in Figure 3 relative to higher stress temperatures.

Cell performance change as a function of temperature and time was used to determine activation energies of degradation. Typical determinations of this type involve plotting $\ln ($ time to failure) as a function of inverse absolute temperature [5]. The resulting Arrhenius plot can then be used to determine activation energies as a function of temperature. A definition of failure equal to a decrease of $10 \%$ total efficiency (relative to the initial measured performance) was used to determine time to failure. This was not an altogether arbitrary value. A $1 \mathrm{eV}$ degradation mechanism tested at an acceleration temperature of $100{ }^{\circ} \mathrm{C}$ for $\sim 700 \mathrm{hrs}$ corresponds to 10 years of service a product use-temperature of $50{ }^{\circ} \mathrm{C}$. Thus, a $10 \%$ degradation in this test is somewhat based upon an approximate degradation rate of $\sim 1 \%$ year.

Figure 7 shows the variation of average deltaEff versus stress time as a function of temperature and the resulting Arrhenius plot obtained from this data assuming a 10\% drop as the definition of failure. Since the \%change in efficiency for devices tested at $60{ }^{\circ} \mathrm{C}$ did not "fail" over the course of nearly $2000 \mathrm{hrs}$ of stress time, a power law fit of the data was required to extrapolate to this level. Curved line fits of the data shown in Figure 7 are based upon the equation:

$$
\text { \%change in Efficiency }(\text { deltaEff })=a \cdot(\text { time })^{b}
$$


where $\mathrm{a}$ and $\mathrm{b}$ were adjusted with an intentional bias towards fitting data where performance was observed to decrease monotonically (i.e., non-increasing) in order to remove transient effects seen at shorter stress times (e.g., Figure 6). The regression coefficients $\mathrm{a}$ and $\mathrm{b}$ were determined by the method of least squares for power-law equations [15].
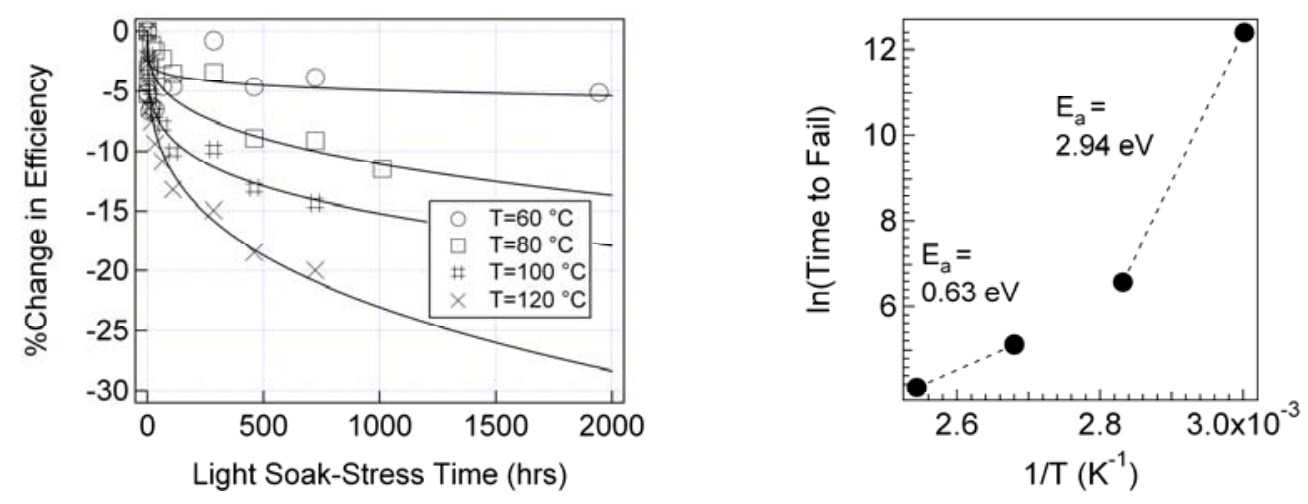

Figure 7. Percent change in cell performance (deltaEff) plotted as a function of stress time (left). Resulting Arrhenius plot (right) showing activation energies calculated from deltaEff plot using the power-law relationship.

The activation energy of $0.63 \mathrm{eV}$ determined from the data at 100 and $120^{\circ} \mathrm{C}$ is a close match to the literature value of $\mathrm{Cu}$ diffusion $(0.67 \mathrm{eV})$ in $\mathrm{CdTe}[16]$. Cu diffusion is thus implicated as being the mechanism responsible for degradation observed at higher stress temperatures. $\mathrm{Cu}$ diffusion also appears to be the mechanism for the short term improvements in FF shown in Figure 6. The FF maxima at 1, 4, 18, and $285 \mathrm{hrs}$ of stress at $\mathrm{T}=120,100,80$, and $60{ }^{\circ} \mathrm{C}$ when combined with the $\mathrm{Cu}$ in CdTe diffusion data from ref.[16] $\left(\mathrm{E}_{\mathrm{a}}=0.67 \mathrm{eV}, \mathrm{D}_{\mathrm{o}}=3.7 \cdot 10^{-4} \mathrm{~cm}^{2} / \mathrm{s}\right)$ result in similar characteristic diffusion distances of between 1.2 and 3.3 microns as shown in Figure 8.

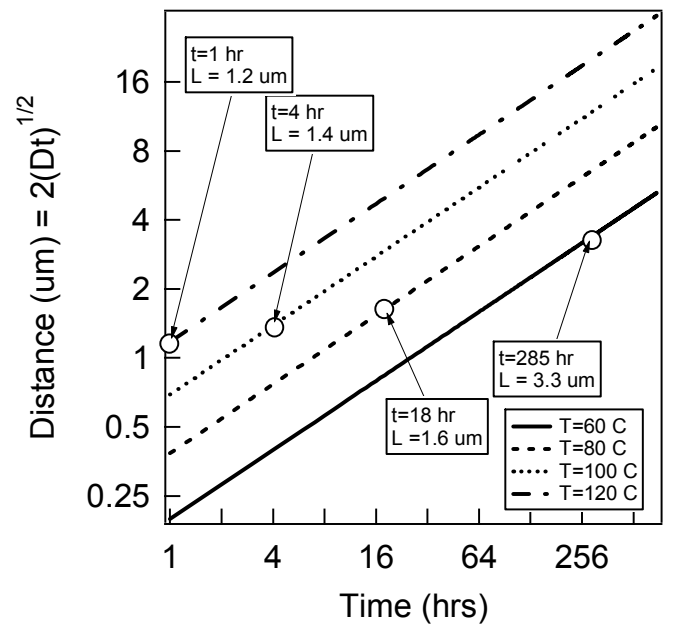

Figure 8. Characteristic diffusion distance corresponding to each FF maxima observed in Figure 6.

The Cu-doped graphite paste back contact in these relatively thick (9-10 micron) cells acts as a semi-infinite source of $\mathrm{Cu}$. $\mathrm{Cu}$ diffusion distances of 1-3 microns from the back contact into CdTe could correspond to a motion of $\mathrm{Cu}$ from the quasi-neutral region into the space-charge (depletion) region. As $\mathrm{Cu}$ migrates from the back contact through the quasi-neutral region, FF increases. Further diffusion into the depletion region results in a decrease in FF.

The higher activation energy of $2.94 \mathrm{eV}$ observed at lower stress temperatures was initially perplexing. It was not quite clear why a mechanism with higher energy requirements would dominate over one with lower activation (e.g., $\mathrm{Cu}$ diffusion at $0.63 \mathrm{eV}$ ). A review of the literature however revealed an interesting possibility. McCandless, et al. reported the grain boundary and bulk diffusion activation energies for $\mathrm{S}$ (from $\mathrm{CdS}$ ) into $\mathrm{CdTe}$ as 2.0 and $2.8 \mathrm{eV}$ 
respectively [17]. The close agreement between these values and the activation degradation energies reported in this study was corroborated further by high-resolution scanning electron microscopy (SEM) images shown in Figure 9 of the $\mathrm{CdS} / \mathrm{CdTe}$ interface of cells before and after stress.
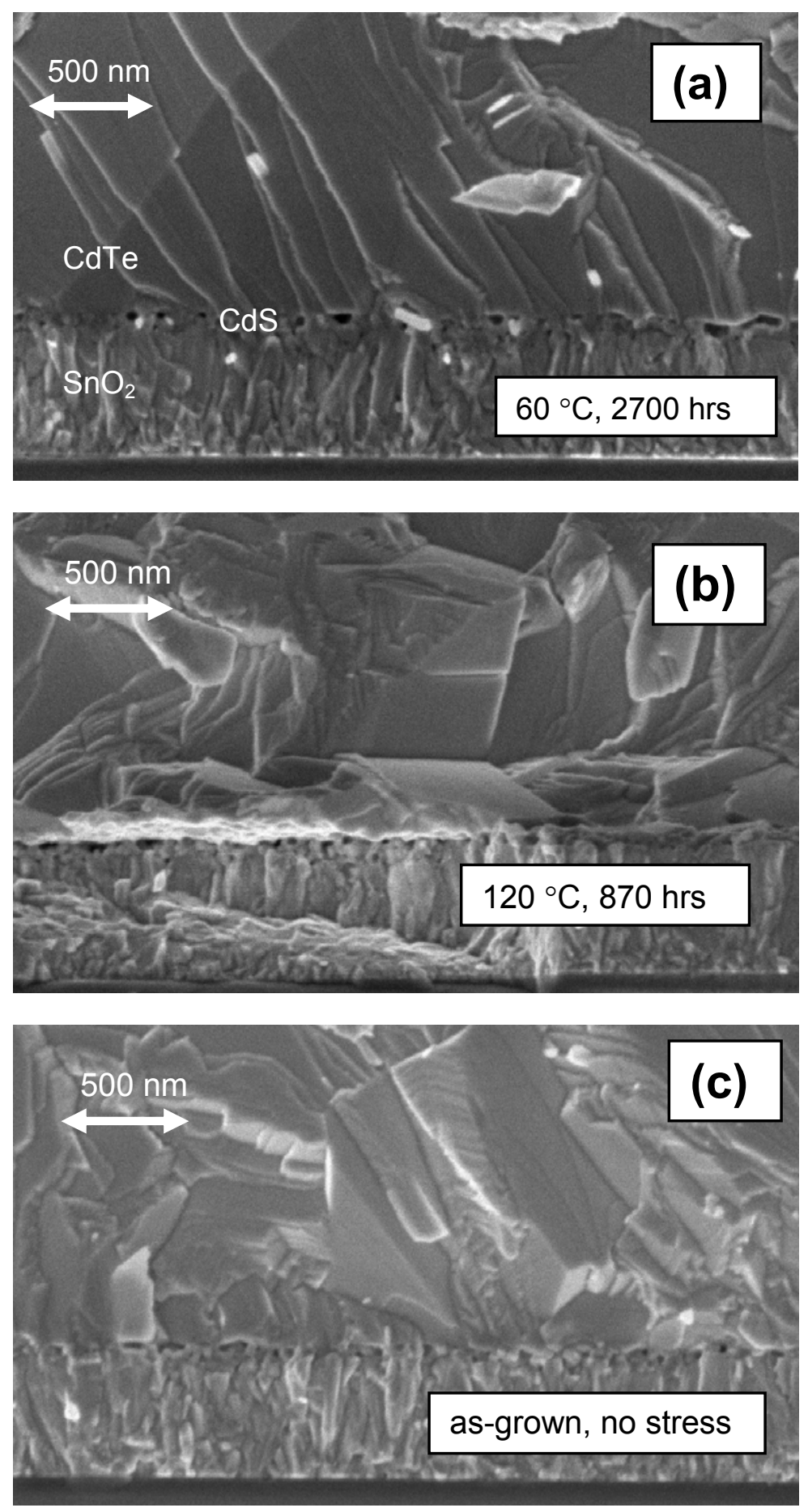

Figure 9. SEM images of the $\mathrm{CdS} / \mathrm{CdTe}$ interface in stressed $\left(\mathrm{T}=60\right.$ (a) and $\left.120^{\circ} \mathrm{C}(\mathrm{b})\right)$ and unstressed (c) cells 
SEM images shown in Figure 9 are intentional, conservative representations of these interfaces. For example, the relatively void-free interface shown for the as-grown, no stress cell was observed along the entire cross-section of the cell. No delamination of the CdTe from the CdS layer was observed. In contrast, the CdTe film for the $120^{\circ} \mathrm{C}$ case had delaminated entirely from the CdS/TCO superstrate in numerous regions not shown in Figure 9. Diffusion of S during stress testing is not unlikely. The open-circuit bias of these cells under stress establishes a field across the cell which aids the diffusion of $\mathrm{Cu}^{+}$from the backcontact and in effect accelerates the degradation of the cell. This same field can be expected to assist the oppositely sensed diffusion of S ions from the CdS into the CdTe film. It is a well accepted fact that interdiffusion at the $\mathrm{CdS} / \mathrm{CdTe}$ interface is not balanced during high temperature processing. At high growth temperatures, S-outdiffusion exceeds the in-diffusion of Te [18]. The Kirkendall effect predicts that such interdiffusion involving asymmetric atomic fluxes will result in a bulk movement of the interface into the CdS, leading to a general "consumption" of that layer, i.e., a 'thinning" of the CdS. This is indeed what is typically observed with CdS/CdTe interfaces joined at high temperature [19]. The Kirkendall effect also suggests that if such bulk movement cannot occur (perhaps at lower temperatures), voids will be introduced in the CdS layer as a consequence of nonequal diffusion rates.

\section{CONCLUSIONS}

The temperature-dependent degradation of 9-10 micron thick CdS/CdTe solar cell devices made using CBDdeposited CdS, and CSS-grown CdTe under open-circuit bias and 1 sun illumination was measured using 6 replicate device structures at four different temperatures in the range 60 to $120^{\circ} \mathrm{C}$. Changes in performance under stress at lower stress temperatures were linearly correlated with changes in both $\mathrm{FF}$ and $\mathrm{J}_{\mathrm{sc}}$. With increasing stress temperature, the correlation between performance change and $\mathrm{FF}$ increases (approaches 1.0) while the correlation with $\mathrm{J}_{\mathrm{sc}}$ is replaced by an even stronger correlation with $\mathrm{V}_{\text {oc }}$ change. At high stress temperatures of $100-120{ }^{\circ} \mathrm{C}$, degradation is characterized by an activation energy of $0.63 \mathrm{eV}$ which is attributed to $\mathrm{Cu}$ diffusion. The diffusion of $\mathrm{Cu}$ results in both increased spacecharge and decreased quasi-neutral region recombination. At lower stress temperatures of $60-80{ }^{\circ} \mathrm{C}$, degradation is characterized by a much higher activation energy of $2.94 \mathrm{eV}$. Outdiffusion of S from the CdS into the CdTe is proposed as the responsible mechanism here. This belief is supported by the observation of Kirkendall-related voids in the CdS layer of stressed cells relative to unstressed cells.

\section{ACKNOWLEDGEMENTS}

This work was supported by the U.S. Department of Energy under Contract No. DE-AC36-99G010337 with the National Renewable Energy Laboratory (NREL). The author also wishes to thank Bobby To for providing the SEM measurements and Wyatt Metzger for discussions concerning device physics.

\section{REFERENCES}

[1] Wu, X., "High efficiency polycrystalline CdTe thin-film solar cells," Solar Energy 77, 803-814 (2004).

[2] Dobson, K., Visoly-Fisher, I., Hodes, G., and Cahen, D., "Stabilizing CdTe/CdS Solar Cells with Cu-Containing Contacts to p-CdTe," Advanced Materials 13(9), 1495-1499 (2001).

[3] Corwine, C., Pudov, A., Gloeckler, M., Demtsu, S., and Sites, J., "Copper inclusion and migration from the back contact in CdTe solar cells, " Sol. Energy Mater. Sol. Cells 82, 481-489 (2004).

[4] Hegedus, S., McCandless, B., "CdTe contacts for $\mathrm{CdTe} / \mathrm{CdS}$ solar cells: effect of $\mathrm{Cu}$ thickness, surface preparation and recontacting on device performance and stability," Sol. Energy Mater. Sol. Cells 88, 85-95 (2005).

[5] Nelson, W., [Accelerated Testing - Statistical Models, Test Plans, and Data Analysis], John Wiley \& Sons, (1990).

[6] Tetali, B., Viswanathan, V., Morel, D., and Ferekides, C., "Effects of Thermal Stressing on CdTe/CdS Solar Cells," Proc. 29th IEEE Photovoltaic Spec. Conf., 600-603 (2002).

[7] Hiltner, J., Sites, J., "Stability of CdTe Solar Cells at Elevated Temperatures: Bias, Temperature, and $\mathrm{Cu}$ Dependence", AIP Conference Proceedings 462 - 15th NREL/SNL Photovoltaics Review Meeting, 170-175 (1998).

[8] Barth, K., Enzenroth, R., and Sampath, W., "Consistent Processing and Long Term Stability of CdTe Devices," Proc. 31st IEEE Photovoltaic Spec. Conf., 323-326 (2005).

[9] Albin, D., Demtsu, S., and McMahon, T., "Film thickness and chemical processing effects on the stability of cadmium telluride solar cells," Thin Solid Films 515, 2659-2668 (2006). 
[10] Levi, D., Albin, D., and King, D., "Influence of Surface Composition on Back-contact Performance in CdTe/CdS PV Devices," Prog. Photovolt: Res. Appl. 8, 591-602 (2000).

[11] Luque, A., Hegedus, S., eds., [Handbook of Photovoltaic Science and Engineering], John Wiley \& Sons, in particular Gray, J., Chapter 3 "The Physics of the Solar Cell,", (2003).

[12] AMPS-1D. A one-dimensional device modeling program written under the direction of S. Fonash, Pennsylvania State University.

[13] Demtsu, S., Sites, J., "Effect of back-contact barrier on thin-film CdTe solar cells," Thin Solid Films 510, 320-324 (2006).

[14] Demtsu, S., Albin, D., and Sites, J., "Role of Copper in the Performance of CdS/CdTe Solar Cells," IEEE - 4th World Conference on Photovoltaic Energy Conversion, 523-526 (2006).

[15] Pachner, J., [Handbook of Numerical Analysis Applications], McGraw-Hill Company, Chapter 9, (1984).

[16] Woodbury, H., Aven, M., "Some Diffusion and Solubility Measurements of Cu in CdTe," J. Appl. Phys. 39(12), 5485-5488 (1968).

[17] McCandless, B., Engelmann, M., and Birkmire, R., "Interdiffusion of CdS/CdTe thin films: Modeling x-ray diffraction line profiles," J. Appl. Phys. 89(2), 988-994 (2001).

[18] Dhere, R., Asher, S., Jones, K., Al-Jassim, M., Moutinho, H., Rose, D., Dippo, P., Sheldon, P., "Characterization of intermixing at the CdS/CdTe interface in CSS deposited CdTe," AIP Conference Proceedings 353 - 13th NREL Photovoltaics Program Review, 392-399 (1995).

[19] Albin, D., Yan, Y., and Al-Jassim, M., "The Effect of Oxygen on Interface Microstructure Evolution in CdS/CdTe Solar Cells," Prog. Photovolt: Res. Appl. 10, 309-322 (2002). 


\section{REPORT DOCUMENTATION PAGE}

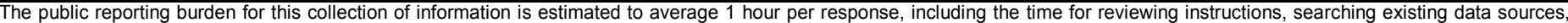

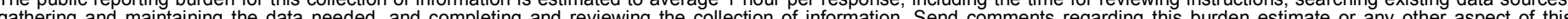

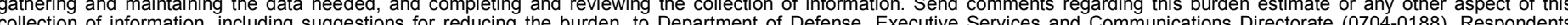

should be aware that notwithstanding any other provision of law, no person shall be subject to any penalty for failing the

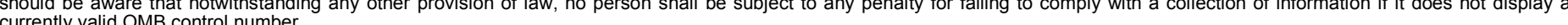

PLEASE DO NOT RETURN YOUR FORM TO THE ABOVE ORGANIZATION.

\begin{tabular}{l|l|l|l} 
1. REPORT DATE $(D D-M M-Y Y Y Y)$ & 2. & REPORT TYPE & 3. DATES COVERED (FrOm - TO)
\end{tabular}

November 2008

Conference Paper

4. TITLE AND SUBTITLE

Accelerated Stress Testing and Diagnostic Analysis of Degradation in CdTe Solar Cells 5a. CONTRACT NUMBER

DE-AC36-08-GO28308

5b. GRANT NUMBER

5c. PROGRAM ELEMENT NUMBER

5d. PROJECT NUMBER

NREL/CP-520-42811

5e. TASK NUMBER

PVB76701

5f. WORK UNIT NUMBER
7. PERFORMING ORGANIZATION NAME(S) AND ADDRESS(ES)

National Renewable Energy Laboratory

1617 Cole Blvd.

Golden, CO 80401-3393
8. PERFORMING ORGANIZATION REPORT NUMBER

NREL/CP-520-42811

9. SPONSORING/MONITORING AGENCY NAME(S) AND ADDRESS(ES)

10. SPONSOR/MONITOR'S ACRONYM(S) NREL

11. SPONSORING/MONITORING AGENCY REPORT NUMBER

12. DISTRIBUTION AVAILABILITY STATEMENT

National Technical Information Service

U.S. Department of Commerce

5285 Port Royal Road

Springfield, VA 22161

13. SUPPLEMENTARY NOTES

14. ABSTRACT (Maximum 200 Words)

The primary goal of this study was to ascertain the presence and types of mechanisms affecting CdS/CdTe device stability in the temperature range of 60 to $120^{\circ} \mathrm{C}$. It should be noted that the results presented were specific to cells made using the specific growth conditions described.

15. SUBJECT TERMS

PV; CdTe solar cell, degradation mechanism, recombination, activation energy, Kirkendall effect

\begin{tabular}{l}
\hline \multicolumn{3}{|l|}{ 16. SECURITY CLASSIFICATION OF: } \\
\begin{tabular}{|l|l|l|}
\hline $\begin{array}{c}\text { a. REPORT } \\
\text { Unclassified }\end{array}$ & b. ABSTRACT & c. THIS PAGE \\
& Unclassified & Unclassified \\
& & \\
\hline
\end{tabular}
\end{tabular}

\begin{tabular}{l|l|} 
17. LIMITATION & 18. $\begin{array}{l}\text { NUMBER } \\
\text { OF PAGES }\end{array}$ \\
OF ABSTRACT & \\
UL & \\
\end{tabular}

19a. NAME OF RESPONSIBLE PERSON

19b. TELEPHONE NUMBER (Include area code) 